\title{
Basin-scale contributions of CR, Ni and Co from Ortegal Complex to the surRounding COASTAL ENVIRONMENT (SW EUROPE)
}

\author{
Ricardo Prego ${ }^{1}$, Miguel Caetano ${ }^{2 *}$, Natalia Ospina-Alvarez ${ }^{1}$ Joana Raimundo ${ }^{2}$ and Carlos Vale ${ }^{2}$ \\ ${ }^{1}$ Marine Research Institute (CSIC), Av. Eduardo Cabello, 36208 Vigo, Spain \\ ${ }^{2}$ IPMA - Portuguese Institute of Sea and Atmosphere, Av. Brasília, 1449-006 Lisbon, Portugal \\ *corresponding author phone: 351.21.3027073; fax: 351.21.3015948; email: mcaetano@ipma.pt
}

\begin{abstract}
The enrichment of $\mathrm{Cr}$ and $\mathrm{Ni}$ in the coastal zones is usually associated with anthropogenic sources such as the tanning, galvanization, ceramic, and cement industries.. However, geological complexes of specific lithologic composition located near shorelines may act as natural sources of metals to the continental shelf. Cape Ortegal (SW Europe) is an ultramafic complex that has $\mathrm{Cr}, \mathrm{Ni}$ and $\mathrm{Co}$ enriched in rocks due to the minerals chromite, chromospinel, gersdorfite and pentlandite.Thus, the hypothesis that this geological complex contributes to metal enrichment in Ortigueira and Barqueiro Rias and the adjacent continental shelf was tested. Chromium, $\mathrm{Ni}$, and Co were determined in water and suspended particulate matter of ria tributaries, rainfall, and surface sediments, mussels, and algae. High contents of $\mathrm{Cr}\left(\max .1670 \mathrm{mg} \cdot \mathrm{kg}^{-1}\right)$ and $\mathrm{Ni}\left(\max .1360 \mathrm{mg} \cdot \mathrm{kg}^{-1}\right.$ ) were found in the sediments surrounding Cape Ortegal and the Ortigueira Ria as a result of erosion of exposed cliffs. Dissolved $\mathrm{Cr}$ and $\mathrm{Ni}$ concentrations in fluvial waters were significantly higher in the rivers that crosses the Ortegal Complex, i.e. Lourido $\left(0.47 \mu \mathrm{gCr} \cdot \mathrm{L}^{-1} ; 9.4 \mu \mathrm{gNi} \cdot \mathrm{L}^{-1}\right)$ and Landoi $\left(0.37 \mu \mathrm{gCr} \cdot \mathrm{L}^{-1} ; 4.3 \mu \mathrm{gNi} \cdot \mathrm{L}^{-1}\right)$, in comparison with the nearby basin out of the complex influence (Sor River: $<0.01 \mu \mathrm{gCr} \cdot \mathrm{L}^{-1} ; 0.57$ $\left.\mu \mathrm{gNi} \cdot \mathrm{L}^{-1}\right)$. The annual fluvial contributions of $\mathrm{Cr}$ and $\mathrm{Ni}$ to the Ortigueira Ria were higher than fluxes into the Barqueiro Ria. Moreover, the increase in $\mathrm{Cr}$ and $\mathrm{Ni}$ in the rainfall in summer demonstrated the importance of the atmosphere pathway for introducing these elements into the aquatic environment. As a consequence, the contents of these metals in soft tissues and shell of mussels and algae from the Ortigueira Ria were higher than organisms from Barqueiro Ria. Thus, geological complexes, such as the Cape Ortegal, located in an uncontaminated area, can increase the land-sea exchange of trace metals.
\end{abstract}

Keywords. Trace metals, land-sea contributions, natural enrichment, bioaccumulation, biomonitoring 


\section{INTRODUCTION}

The composition of coastal surface sediments is influenced by river-derived material and hence by the geologic nature of the catchment area (Cho et al., 1999). Weathering of rocks from river basins introduces mineral constituents to natural waters that are transported to coastal zones in dissolved and particulate forms. Metals in the dissolved fraction are adsorbed to suspended material, incorporated in the lattice of freshly formed inorganic compounds such as Al, Fe and Mn (oxy)hydroxides, or sorbed onto organic matter. Generated particles or eroded material will settle in margins, flood plains, and other low hydrodynamic zones. Additionally, human activities also introduce metals in aquatic environment as a result of industries and urban development (Förstner, 1987).

Anthropogenic inputs of chromium ( $\mathrm{Cr})$, nickel $(\mathrm{Ni})$, and cobalt $(\mathrm{Co})$ to waterways are associated with industries of tanning, galvanization, and coke, ceramic and cement production (Fendorf et al., 2000; Turner, 2000). Inputs of these metals to coastal environments may also result from inputs of lithogenic components associated with rocks with specific petrography (Firek et al., 1977). Weathering of ultramafic rocks, namely those enriched in serpentine, may result in introduction of $\mathrm{Cr}, \mathrm{Ni}$ and $\mathrm{Co}$ into the aquatic environment (Schreier et al., 1987; Alexander et al., 1989; Gasser and Dhlgreen, 1994). Thus in areas with this type of geologic setting natural and anthropogenic sources for these elements should be considered.

Several essential metabolic functions are known for $\mathrm{Cr}, \mathrm{Ni}$ and $\mathrm{Co}$ at low environmental concentrations (Merian, 1991; Goyer, 1991; Bowen, 1996), however, concern has been expressed regarding elevated values in water due to the potential toxic and carcinogenic effects (Fendorf et al., 2000). To our knowledge the relationship between naturally high concentration of these elements in sediments, and the availability in water and aquatic organisms has not been investigated.

The characterization of geology and geochemical composition of marine sediments from the southwestern Europe has been mainly focused on western rias (submerged unglaciated river valley) (e.g. Rubio et al., 2001; Vilas et al., 2005; Prego et al., 2009). A review by Prego and Cobelo-García (2003) on the state of knowledge of metal biogeochemical cycles in the Galician Rias point out that few works were performed in the northern Galician Rias (Barqueiro and Ortigueira Rias). Otero et al. (2000) investigated the distribution of $\mathrm{Cr}$ and $\mathrm{Ni}$ in river sediments and salt marsh soils of the Ortigueira Ria and suggested that metal increases may be associated with the sludge from a nearby dunite mine. Later, Lorenzo et al. (2007) studied the record of sediment contamination since 1910 in the Northern Galician Rias pointing out that in Ortigueira River enhanced contents of $\mathrm{Cu}$ and $\mathrm{Co}$ observed were presumably 
derived from a discontinued mining activity while high levels of $\mathrm{Cr}$ are associated with local lithology.

The Northern Galician coast is composed of the Cape Ortegal Ultramafic Complex, which is composed by ultrabasic rocks (Gil-Ibarguchi et al., 1990; Peucat et al., 1990) that are enriched in chromium and nickel minerals (Mirre, 1990; Moreno et al., 2001). Regional variations of the mineral assemblages in the northern Galician shelf are governed by the source-rock composition of different mineralogy (Bernárdez et al., 2012). Mineralogical composition of the Ortigueira Ria and adjacent shelf sediments are controlled by mafic and ultramafic rocks of the Ortegal Cape complex (Bernárdez et al., 2012). On this basis, the coastal environment around the abovementioned landmass was studied to evaluate the transport of weathered material.

The hypothesis that $\mathrm{Cr}, \mathrm{Ni}$, and $\mathrm{Co}$ derived from geological features with consequent enrichment in sediments and target organisms was tested in this northwestern area of the Iberian Peninsula (Fig. 1). To test this hypothesis the study had the following the specific objectives: (i) quantify the metal fluxes in fluvial and rain waters; (ii) evaluate the metal natural enrichment and the labile fraction in coastal and ria sediments; and (iii) assess the metal impact on biomonitoring species: mussels (Mytilus galloprovincialis) and algae (Fucus vesiculosus).

\section{MATERIAL \& METHODS}

\subsection{Study area}

The northern coast of Galicia includes the Ortigueira and Barqueiro Rias and the Capes Ortegal and Estaca-de-Bares (southwester of continental Europe). Both rias are part of Northern Galician Rias (Iberian Peninsula), located in the western boundary of the Cantabrian coast and surrounded by different geological domains (Fig.1). Cape Ortegal, which is the west shore of Ortigueira Ria, includes the Ortegal allochthonous complex with abundant ultramafic rocks and metaigneous granulites, lower metamorphic facies with pyroxenes, eclogites, amphibolite and serpentinites (Dallmeyer et al, 1997; Martínez-Catalán et al., 1996; Peucat et al., 1990; Gil-Ibarguchi et al., 1990). Minerals incorporated in these rocks with high content of $\mathrm{Cr}$ and $\mathrm{Ni}$ are chromite $\left(\mathrm{Cr}_{2} \mathrm{O}_{3} \mathrm{FeO}\right)$ and chromospinel $\left((\mathrm{Fe}, \mathrm{Mg})(\mathrm{Cr}, \mathrm{Al}, \mathrm{Fe})_{2} \mathrm{O}_{4}\right)$, gersdorfite (NiAsS) and pentlandite $\left((\mathrm{Fe}, \mathrm{Ni})_{9} \mathrm{~S}_{8}\right)$ (Mirre, 1990; Gent et al., 2005). Barqueiro Ria is to the east and the surrounding lithology is dominated by a autochthon metamorphic (mainly gneisses) and granite-type rocks composing the series occupying the Ollo de Sapo Domain (IGME, 1977; Aparicio et al, 1987; Marcos, 2004).

The Ortigueira Ria has a wide entrance protected by the Cape Ortegal. It is a wedge-shaped ria open to NE occupying $38 \mathrm{~km}^{2}$ (Fig.1). The freshwater inputs are due to Lourido, Landoi and 
Mera Rivers. The western shoreline of the Barqueiro Ria is the Cape Estaca-de-Bares. This ria covers $10 \mathrm{~km}^{2}$ and the Sor River drains directly into the head of the ria. Both mesotidal rias are characterized by strong currents in periods of high tidal ranges ( 3 to $4 \mathrm{~m}$; Lorenzo et al., 2007). The land area close to the surveyed zone has a population density of 48 inhabitants per $\mathrm{km}^{2}$ devote mainly to agriculture, timber, and shell and coastal fishing. The climate is wet temperate oceanic (Cfb Köppen type). During the sampling year (2008) the annual average air temperature in the area was $10.4^{\circ} \mathrm{C}$ with a thermal fluctuation of $8^{\circ} \mathrm{C}$ and an average value of humidity of $80 \%$. The wind regime is characterized by westerly winds in autumn-winter, while in spring and summer easterly winds prevail.

\subsection{Sampling}

Sediments. Seventy two bottom sediments were sampled in Ortigueira and Barqueiro Rias and adjacent shelves (Fig.1) from the research vessels Mytilus and Lura, and small boats in the shallow zones. Samples were collected during 2007 to 2008 using Van Veen grabs. The topmost sediments $(0$ to $1 \mathrm{~cm}$ ) were taken with a plastic spatula, stored in pre-cleaned LDPE vials and kept at $4^{\circ} \mathrm{C}$. Sediment was freeze dried and the coarse fraction was separated with a $2 \mathrm{~mm}$ sieve (Retsch AS200). The $<2 \mathrm{~mm}$ fraction was homogenized and ground with an agate mortar for further analysis.

Water. River water was sampled from January to December 2008 every 3 to 4 weeks in the rivers Mera (16 samples), Landoi (15 samples) and Lourido (16 samples) that flow to the Ortigueira Ria, and fortnightly in Sor River (24 samples) running into Barqueiro Ria (Fig.1). Duplicate samples were collected in 1-L LDPE bottles.

Rain samples (wet deposition) were collected at the meteorological station of Spanish Meteorological Agency (AEMet) located in Cape Estaca-de-Bares $\left(7^{\circ} 41.1^{\prime} \mathrm{N} ; 43^{\circ} 47.2^{\prime} \mathrm{W}\right.$; Fig. 1 ) $\approx 80 \mathrm{~m}$ above sea level. The collection system consisted of twin funnels of low-density polyethylene (LDPE) attached to a LDPE bottle. Composite samples resulted from mixing the collected material from two samples. Twenty five precipitation samples were collected on a fortnightly basis during 2008. All sampling devices were previously acid-washed for a week, rinsed, and filled with Milli-Q water $(18.2 \mathrm{M} \Omega \mathrm{cm})$ prior to their use. Dissolved and particulate fractions of water samples (fluvial and rain) were separated in a laminar flow (ISO Class 5) by filtration through polycarbonate membranes $(0.45 \mu \mathrm{m})$, previously acid washed (Suprapure $\mathrm{HCl}$ $1 \%)$ and weighed. Samples for dissolved trace elements analysis were acidified with Suprapure $\mathrm{HNO}_{3}(\mathrm{pH}<2)$. Particle retained membranes were dried at $40^{\circ} \mathrm{C}$, weighed to calculate the concentration of particulate matter and stored for metal analysis. Results of trace elements in 
rain samples are given as total concentrations (dissolved + particulate) while in river waters data from particulate and dissolved fractions are provided separately.

Organisms. Samples of mussels (Mytilus galloprovincialis) and algae (Fucus vesiculosus) were collected in Ortigueira and Barqueiro Rias in spring (April) and summer (June) 2008 (Fig.1). Organisms (up to 20 individuals of mussels and 5 entire thalli of algae) were collected close to the mouths of Lourido and Sor Rivers.To avoid differences in metal content with size, only mussels between 4 and $5 \mathrm{~cm}$ were gathered at each site. The total edible portion of the mussels was removed, homogenized, frozen at $-20^{\circ} \mathrm{C}$ and freeze dried for metal analysis. Shells were mechanically cleaned from parasite and other attached organisms, grounded and homogenized in an agate mortar and stored for further metal analysis. To minimize differences of age/size the collected thalli of algae had similar size. Fucus thallus was washed with Milli-Q water to remove visible epiphytes, organic animal debris, and adherent sediment particles. Then, samples were frozen at $-20^{\circ} \mathrm{C}$, freeze dried, homogenized and ground with an agate mortar for further analysis.

\subsection{Analytical methods}

Aluminum and $\mathrm{Mg}$ analysis were carried out using $\approx 100 \mathrm{mg}$ of sediment that were completely digested with $6 \mathrm{~cm}^{3}$ of $\mathrm{HF}(40 \%)$ and $1 \mathrm{~cm}^{3}$ of Aqua Regia ( $\mathrm{HCl}-36 \%$ : $\mathrm{HNO}_{3}-60 \%$; 3:1) in closed Teflon bombs at $100^{\circ} \mathrm{C}$ for 1 hour (Rantala and Loring, 1975). To the bombs contents was added $2.8 \mathrm{~g}$ of boric acid and fulfilled to $50 \mathrm{~cm}^{3}$ with ultrapure Milli-Q water. Both metals were analyzed by flame atomic absorption spectrometry (Perkin Elmer AA100) with a nitrous oxide-acetylene flame. Concentrations were determined with the standard additions method.

For the analysis of $\mathrm{Cr}, \mathrm{Ni}$ and $\mathrm{Co}$, sediments $(\approx 100 \mathrm{mg})$ and suspended particulate matter (SPM) were digested using $\mathrm{HF}-\mathrm{HNO}_{3}-\mathrm{HCl}$ in the volume proportions indicated above and the obtained residue evaporated to near dryness in Teflon vials (DigiPrep HotBlock). The residue was redissolved with $1 \mathrm{~cm}^{3}$ of $\mathrm{HNO}_{3}$ and $5 \mathrm{~cm}^{3}$ of Milli-Q water, heated for 20 min at $75^{\circ} \mathrm{C}$, added $25 \mathrm{~cm}^{3}$ of Milli-Q water, heated for $20 \mathrm{~min}$ at $90^{\circ} \mathrm{C}$ and diluted to $50 \mathrm{~cm}^{3}$ with Milli-Q water (Caetano et al., 2008). The edible portion of mussels ( $\approx 200 \mathrm{mg}$ ) was digested with a mixture of $4 \mathrm{~cm}^{3} \mathrm{HNO}_{3}(60 \%)$ and $2 \mathrm{~cm}^{3} \mathrm{H}_{2} \mathrm{O}_{2}$ (30\%) in Teflon bombs at different temperatures (Ferreira et al., 1990). Mussel shells ( $\approx 500 \mathrm{mg}$ ) were weighed to a Teflon vessel and completely digested with a mixture of $8 \mathrm{~cm}^{3}$ of $\mathrm{HNO}_{3}(69 \%)$ and $4 \mathrm{~cm}^{3}$ of Milli-Q water in a Mars-X-Press CEM microwave oven and diluted to $50 \mathrm{~cm}^{3}$. Algae samples were digested with $2 \mathrm{~cm}^{3}$ of $\mathrm{HNO}_{3}$ and $\mathrm{HClO}_{4}$ in a 7:1 proportion in closed Teflon bombs at $110^{\circ} \mathrm{C}$ for 3 hours following the method described by Otte (1991). Two procedural blanks were prepared using similar analytical 
procedures and reagents, and included within each batch of 10 samples. Total concentrations of $\mathrm{Cr}, \mathrm{Ni}$ and $\mathrm{Co}$ in water, sediments and biota were determined using a quadrupole ICP-MS (Thermo Elemental, X-Series) equipped with a Peltier Impact bead spray chamber and a concentric Meinhard nebulizer. The experimental parameters were: forward power $1400 \mathrm{~W}$; peak jumping mode; 150 sweeps per replicate; dwell time $10 \mathrm{~ms}$; dead time $50 \mathrm{~ns} .{ }^{115} \mathrm{In}$ was the internal standard chosen. Two 7-points calibration curves with different ranges were used to quantify metal concentrations: $0.1-25 \mathrm{~g} \cdot \mathrm{L}^{-1}$ for water samples; and $1-100 \mathrm{~g} \cdot \mathrm{L}^{-1}$ for sediment and organisms. Coefficients of variation for metal counts $(n=5)$ were lower than $2 \%$.

The labile fraction in surface sediments was determined according to Quevauviller et al. (1997) by the first step sequential extraction scheme of the Standards, Measurement and Testing (SM\&T) of the EU Commission. Dry sediment samples ( $\approx 500 \mathrm{mg}$ ) were treated with 20 $\mathrm{cm}^{3}$ of $0.11 \mathrm{M}$ acetic acid under constant stirring (16 h at $\left.22^{\circ} \mathrm{C}\right)$. After extraction, sediments were centrifuged for $20 \mathrm{~min}$ at $3000 \mathrm{rpm}$ and the supernatant separated from the solid phase. This labile phase represents an operationally-defined fraction that comprises mainly metals weakly bound to sediment particles and associated with carbonate minerals. Labile $\mathrm{Cr}$ and $\mathrm{Ni}$ were analyzed by graphite furnace atomic absorption spectrometry (Varian SpectrAA 220) equipped with Zeeman background correction. Concentrations were determined with the standard additions method. Procedural blanks always accounted for less than $3 \%$ of the metal concentrations in samples.

The precision and accuracy of each metal concentration measurements was controlled by repeated analysis of certified references materials (PACS-2 and BCR 701 for sediment, NBS1566a for biological material and SLRS-5 for freshwater). Metal concentrations obtained (Table 1) were not statistically different from their certified ones ( $t$-student; $\alpha=0.05$ ).

Grain size analyses were performed in sediments by dry sieving (Retsch AS-200). Sampled sediments were classified as mud, sand and gravel fractions, according to the UddenWentworth scale (from $<63 \mu \mathrm{m}$ to $>2 \mathrm{~mm}$ ). Carbon content was measured in homogenized and dried sediments, using a CHN Fisons NA 1500 Analyzer. Procedural blanks were obtained by running several empty ash tin capsules. Organic carbon was estimated by the difference between total carbon and inorganic carbon after heating samples at $450^{\circ} \mathrm{C}$ for $2 \mathrm{~h}$.

\subsection{Statistical analysis}

Prior to statistical analyses, metal concentrations were tested for normality and equality of variances. Non-compliance with parametric ANOVA assumptions led to employment of the Kruskal-Wallis $\mathrm{H}(\mathrm{KW}-\mathrm{H})$ and Mann-Whitney $(\mathrm{U})$ non-parametric tests. Differences in trace element concentration were evaluated between both rias and between rivers in dissolved 
fraction, SPM, sediments, mussels and algae. The significance for statistical analyses used was always $p<0.05$. The statistical analyses were performed using STATISTICA 6 (Statsoft).

\section{RESULTS}

\subsection{Sediment composition}

The grain size distribution in sediment samples pointed to the predominance of sand in the shelf $(94 \pm 6 \%)$ while fine-grained material was only present in samples from the innermost part of Rias (Fig. 2). Organic carbon content was lower in sand $(<1.4 \%)$ than in muddy sediments reaching $13 \%$ at innermost Barqueiro Ria (data not shown). Aluminium varied from $1.9 \mathrm{~g} \cdot \mathrm{kg}^{-1}$ in sand from the shelf to $66 \mathrm{~g} \cdot \mathrm{kg}^{-1}$ in mud sediments from some inner bays of rias with low hydrodynamics (Fig. 2). No significant relationships ( $p>0.05$ ) were found between Al content and the grain size indicating that sediment nature is not fully explained by the variation of aluminosilicates. Elevated Mg concentrations were found in the shelf sediments around Cape Ortegal (max. $130 \mathrm{~g} \cdot \mathrm{kg}^{-1}$ ), decreasing eastward until $7.3 \mathrm{~g} \cdot \mathrm{kg}^{-1}$ in sands nearby to Barqueiro Ria (Fig. 2). A tendency to $\mathrm{Mg}$ decrease was also found towards the inner parts of both rias: 17 to $79 \mathrm{~g} \cdot \mathrm{kg}^{-1}$ in the Ortigueira Ria and 5 to $35 \mathrm{~g} \cdot \mathrm{kg}^{-1}$ in the Barqueiro Ria.

Spatial distribution patterns of $\mathrm{Cr}, \mathrm{Ni}$ and $\mathrm{Co}$ were similar to $\mathrm{Mg}$, showing elevated values in sediments surrounding the Cape Ortegal (Fig. 2). Chromium in the shelf was significantly $(p<0.05)$ higher nearby this geological feature $\left(760\right.$ to $\left.1670 \mathrm{mg} \cdot \mathrm{kg}^{-1}\right)$ decreasing gradually to 126 $\mathrm{mg} \cdot \mathrm{kg}^{-1}$ in the eastern station. The decrease of $\mathrm{Cr}$ in sediments from the mouth to the rias innermost part was also observed for Ortigueira and Barqueiro Rias, ranging from 1340 to 198 $\mathrm{mg} \cdot \mathrm{kg}^{-1}$ and from 412 to $22 \mathrm{mg} \cdot \mathrm{kg}^{-1}$, respectively. Nickel concentrations in shelf sediments varied within two orders of magnitude from 75 to $1360 \mathrm{mg} \cdot \mathrm{kg}^{-1}$. Higher levels $(p<0.05)$ were found in sediments of the Ortigueira Ria (87-621 mg.kg $)$ than in the Barqueiro Ria (2.7-156 $\left.\mathrm{mg} \cdot \mathrm{kg}^{-1}\right)$. The spatial variability of Co concentrations in shelf sediments also mimics the $\mathrm{Mg}$ with a gradual decrease from Cape Ortegal towards east: 70 to $4.7 \mathrm{mg} \cdot \mathrm{kg}^{-1}$ in the shelf; 36 to 9.7 $\mathrm{mg} \cdot \mathrm{kg}^{-1}$ at Ortigueira (from the mouth to ria head); and 12 to $1.1 \mathrm{mg} \cdot \mathrm{kg}^{-1}$ at Barqueiro Ria.

Levels of $\mathrm{Cr}, \mathrm{Ni}$ and $\mathrm{Co}$ in sediments from the shelf and Ortigueira and Barqueiro Rias showed no significant correlations ( $p>0.05$ ) with Al indicating that these trace elements are not associated with aluminosilicates and their distribution in sediments is poorly correlated with grain-size. Conversely, significant correlations $(\mathrm{p}<0.05)$ were found with $\mathrm{Mg}$ vs. $\mathrm{Cr}, \mathrm{Ni}$ and $\mathrm{Co}$ (Fig. 3) suggesting that $\mathrm{Mg}$ may be used as a tracer for particle origin and transport. Furthermore, significant correlations $(\mathrm{p}<0.01)$ between $\mathrm{Cr}$ and $\mathrm{Ni}$ and $\mathrm{Co}$ were also found for all sediment samples pointing to similar origin of these trace elements (Fig. 3). 
The labile fraction of $\mathrm{Cr}$ and $\mathrm{Ni}$ in the shelf samples near the Cape Ortegal was 1.7 and 11 $\mathrm{mg} \cdot \mathrm{kg}^{-1}$, corresponding to $0.1 \%$ and $0.8 \%$ of the total concentration, respectively. Lower proportions were found eastward from the cape, 0.01 to $0.04 \%$ for $\mathrm{Cr}$ and 0.1 to $0.5 \%$ for $\mathrm{Ni}$. The percentage of the $\mathrm{Cr}$ and $\mathrm{Ni}$ labile fractions presented similar intervals in sediments from the two surveyed Rias ( $\mathrm{Cr} 0.01$ to $0.31 \%$; Ni 0.11 to $9.1 \%$ ). Differences in grain size contributed to the larger variations registered in this fraction. Accordingly, sand contained lower labile fractions of $\mathrm{Cr}(<0.02 \%)$ and $\mathrm{Ni}(0.11$ to $0.70 \%)$ than mud ( $\mathrm{Cr} 0.20$ to $0.30 \%$; Ni 5.5 to $9.1 \%)$.

\subsection{Cobalt, $\mathrm{Cr}$ and $\mathrm{Ni}$ in rain water}

Average daily rainfall between January and December 2008 was lower in summer $\left(0.74 \mathrm{~L} \cdot \mathrm{m}^{-}\right.$ $\left.{ }^{2} \cdot \mathrm{d}^{-1}\right)$, and higher in winter $\left(1.40 \mathrm{~L} \cdot \mathrm{m}^{-2} \cdot \mathrm{d}^{-1}\right)$ and spring $\left(2.33 \mathrm{~L} \cdot \mathrm{m}^{-2} \cdot \mathrm{d}^{-1}\right)$ (Fig. 4). Conversely, the total metal concentration in rainfall increased during the dry season. This was on average 3 times in the summer with regard to winter. This is hypothesized to be due to airborne particle deposition in the sampler or increased entrainment in precipitation due to dust?

Cobalt concentrations were up to one order of magnitude lower than concentrations of $\mathrm{Cr}$ and $\mathrm{Ni}$. Concentrations of $\mathrm{Co}, \mathrm{Cr}$, and $\mathrm{Ni}$ showed a seasonal variation with pronounced peaks (max. levels: $2.6 \mu \mathrm{gCo} \cdot \mathrm{L}^{-1} ; 14 \mathrm{Cr} \mu \mathrm{g} \cdot \mathrm{L}^{-1} ; 17 \mu \mathrm{gNi} \cdot \mathrm{L}^{-1}$ ) in the lower rainfall period from July to October 2008 (200-280 Julian days; Fig. 4). Likewise, the minor precipitation in March 2008 (120 Julian days) resulted in an increase of metals concentration in rain, but no significant correlations were found between these two parameters. During the periods of increased rain (higher than $1 \mathrm{~L} \cdot \mathrm{m}^{-2} \cdot \mathrm{d}^{-1}$ ) metal concentrations reached very low values namely in OctoberNovember 2008, even during summer (i.e. September, 250 Julian days; Fig.4). The parallel temporal variability of $\mathrm{Co}, \mathrm{Cr}$, and Ni levels was also evident with the strong correlations among them $(0.81<r<0.95 ; p<0.001)$. On the basis of metal concentration in dissolved and particulate fractions and the on rainfall data, the total fluxes of $\mathrm{Co}, \mathrm{Cr}$ and $\mathrm{Ni}$ were calculated (Fig. 4). Fluxes showed a clear increase during the lower rainfall season, which correspond to higher concentrations samples. Moreover, this metal concentration rise occurred in Cape Estaca-de-Bares was positively related with the wind velocity from the west quadrant (Fig. 5) suggesting that particles were due to soil resuspension.

\subsection{Cobalt, $\mathrm{Cr}$ and $\mathrm{Ni}$ in fluvial waters}

The three rivers (Lourido, Landoi and Mera) discharging into the Ortigueira Ria exhibited seasonal flows with maximum discharges in winter and spring (average values: 1.8, 3.9 and 23 $\mathrm{m}^{3} \cdot \mathrm{s}^{-1}$, respectively) and low flows in summer (average values: $0.1,0.3$ and $1.7 \mathrm{~m}^{3} \cdot \mathrm{s}^{-1}$, respectively). A similar pattern was found for the Sor River running into the Barqueiro Ria 
although flows were higher (average values: summer $8.2 \mathrm{~m}^{3} \cdot \mathrm{s}^{-1}$, winter $32 \mathrm{~m}^{3} \cdot \mathrm{s}^{-1}$ ). Median concentrations of suspended particulate matter found in Lourido, Landoi, Mera, and Sor (1.1, $2.1,1.6$, and $0.86 \mathrm{mg} \cdot \mathrm{L}^{-1}$, respectively) were not statistically different. Metal concentrations in both dissolved and particulate fractions exhibited no consistent seasonal variations

Figure 6 shows the median, percentiles $25 \%$ and $75 \%$, minimum and maximum concentrations of $\mathrm{Co}, \mathrm{Cr}$ and $\mathrm{Ni}$ in the dissolved and particulate fractions of Lourido, Landoi, Mera, and Sor Rivers. Dissolved cobalt concentrations were not statistically different $(p>0.05)$ between the three rivers flowing into the Ortigueira Ria, although being significantly $(p<0.05)$ higher than the values of the Sor River (Barqueiro Ria). A different pattern was found for dissolved $\mathrm{Cr}$ and $\mathrm{Ni}$ with significantly $(\mathrm{p}<0.05)$ higher median concentrations in Lourido River $\left(0.55 \mu \mathrm{gCr} \cdot \mathrm{L}^{-1} ; 11.4 \mu \mathrm{gNi} \cdot \mathrm{L}^{-1}\right)$ and Landoi River $\left(0.39 \mu \mathrm{gCr} \cdot \mathrm{L}^{-1} ; 4.8 \mu \mathrm{gNi} \cdot \mathrm{L}^{-1}\right)$ than in Mera and Sor Rivers $\left(<0.1 \mu \mathrm{gCr} \cdot \mathrm{L}^{-1} ;<0.9 \mu \mathrm{gNi} \cdot \mathrm{L}^{-1}\right)$. Concentrations of three dissolved metals were strongly correlated $(0.82<r<0.91 ; p<0.01)$ with the flow of the Lourido River. Conversely, in the other two rivers of Barqueiro Ria (Landoi and Mera) no significant relationships ( $p>0.05$ ) were found. Dissolved concentrations of $\mathrm{Co}$ and $\mathrm{Ni}$ in the Sor River (Barqueiro Ria) were also strongly correlated $(0.92<r<0.95 ; p<0.01)$ with the river flow. Since $\mathrm{Cr}$ levels were always below the detection limits this relationship could not be investigated in the Sor River. Similar spatial differences were also found for $\mathrm{Cr}$ and $\mathrm{Ni}$ in the river suspended particulate matter while $\mathrm{Co}$ showed minor differences between rivers. Average concentration of metals in particulate matter were 3 to 4 times higher in the Ortegal fluvial basins, i.e. 589 and $586 \mathrm{mgCr} \cdot \mathrm{kg}^{-1}$ and 776 and $891 \mathrm{mgNi} \cdot \mathrm{kg}^{-1}$ in Lourido and Landoi Rivers, respectively, vs. 210 and $178 \mathrm{mgCr} \cdot \mathrm{kg}^{-1}$ and 137 and $33 \mathrm{mgNi} \cdot \mathrm{kg}^{-1}$ in Mera and Sor Rivers (Fig. 6).

\subsection{Cobalt, $\mathrm{Cr}$ and $\mathrm{Ni}$ in organisms}

Cobalt, $\mathrm{Cr}$ and $\mathrm{Ni}$ contents in the edible tissues and shell of the mussel Mytilus galloprovincialis and in tissues of the algae Fucus vesiculosus sampled at the two rias inlets are given in Table 2. Cobalt values in the three analyzed matrices were always below the detection limit. Mussel soft tissues had concentrations of $\mathrm{Cr}\left(1.6-3.5 \mathrm{mg} \cdot \mathrm{kg}^{-1}\right)$ and $\mathrm{Ni}\left(1.4-6.9 \mathrm{mg} \cdot \mathrm{kg}^{-1}\right)$ up to three orders of magnitude above those registered in the shell $\left(\mathrm{Cr}: 0.01-0.21 \mathrm{mg} \cdot \mathrm{kg}^{-1}\right.$; Ni: 0.01-0.32 $\left.\mathrm{mg} \cdot \mathrm{kg}^{-1}\right)$. Chromium and $\mathrm{Ni}$ in the whole soft tissues of mussels from Ortigueira Ria (average: $2.5 \mathrm{mgCr} \cdot \mathrm{kg}^{-1} ; 4.1 \mathrm{mgNi} \cdot \mathrm{kg}^{-1}$ ) were significantly higher $(\mathrm{p}<0.05)$ than those from Barqueiro Ria $\left(1.9 \mathrm{mgCr} \cdot \mathrm{kg}^{-1} ; 2.4 \mathrm{mgNi} \cdot \mathrm{kg}^{-1}\right)$. Otherwise, only Ni concentrations in mussel shells were statistically higher $(p<0.05)$ in Ortigueira Ria $\left(0.13 \mathrm{mg} \cdot \mathrm{kg}^{-1}\right)$ than in Barqueiro Ria $(0.03$ $\mathrm{mg} \cdot \mathrm{kg}^{-1}$ ). Minor differences were found for $\mathrm{Cr}$ medians, 0.092 and $0.036 \mathrm{mg} \cdot \mathrm{kg}^{-1}$, respectively. Chromium and $\mathrm{Ni}$ concentrations in Fucus were higher than mussel tissue and exhibited 
abroader range, $1.3-21 \mathrm{mg} \cdot \mathrm{kg}^{-1}$ and $8.5-46 \mathrm{mg} \cdot \mathrm{kg}^{-1}$, respectively, higher values having been registered in samples from Ortigueira Ria.

\section{DISCUSSION}

The current work demonstrates the influence of the Ortegal Complex on the spatial distribution of $\mathrm{Cr}, \mathrm{Ni}$ and $\mathrm{Co}$ in the shelf sediments (Fig. 2 and 3). Elevated concentrations of these elements in sediments is occurring due to the erosion of exposed coastal cliffs from Cape Ortegal and adjacent beaches. Fluvial input is also a major source of fine detrital material to the rias (Bernárdez et al., 2012). Erosion of igneous, plutonic, mafic, ultramafic and metamorphic rocks enriched in chromite, chromospinel, gersdorfite and pentlandite that is present in the Ortegal Complex (Mirre, 1990; Gent et al., 2005). The abundance of Mg in minerals (illite and riebeckite) in the geological complex (Bernárdez et al., 2012) makes this element useful as a potential tracer of particle transport and this is supported by the strong correlations with $\mathrm{Cr}, \mathrm{Ni}$ and $\mathrm{Co}$. Here, unlike often observed in estuaries and marine sediments (Windom et al., 1989), the variability of these trace elements in sediments was not explained by the aluminosilicate fraction but by the mineral fraction enriched in Mg. Lorenzo et al. (2007) suggested that increased $\mathrm{Cr}$ and $\mathrm{Co}$ concentrations in a sediment core at Ortigueira Ria could be linked with ultramafic rocks of the Cape Ortegal; these rocks contain platiniferous chromites (Moreno et al., 2001). This finding is confirmed here by the distribution of these elements in coastal sediments and corroborated with the strong correlations showed between their concentrations. There is no $\mathrm{Cr}$ or Ni mining in Ortegal, so the erosion of basic and ultrabasic rocks has supplied the littoral with sediments particles enriched in these metals, i.e. in intertidal (Carballeira et al. 2000) and salt march (Otero et al. 2000) areas. Similar land-shelf contribution was observed in sediments from the Black Sea by Kiratli and Erguin (1996), who related their high $\mathrm{Ni}$ and $\mathrm{Cr}$ concentrations to the presence of ultramafic substrates in the Turkish coasts. Moreover, ultramafic rocks are also cited as a $\mathrm{Cr}$ source by Hornberger et al. (1999) for San Francisco Bay, California. The low labile fraction of $\mathrm{Cr}$ and $\mathrm{Ni}$ indicates that both metals are mainly in refractory sediment fractions. These results are in line with association of these elements with the silicate fraction found in sediments of the Origueira salt marsh (Otero et al, 2000). Concentrations of $\mathrm{Cr}, \mathrm{Ni}$ and $\mathrm{Co}$ in Ortigueira Ria were approximately one order of magnitude below those found in the coastal zone. In spite of this difference concentrations of these metals were higher than those found in most of Galician rias of the NW Iberian Peninsula (cf. Prego and Cobelo-Garcia, 2003). Levels of $\mathrm{Cr}$ and $\mathrm{Ni}$ in Vigo and La-Coruña Rias, which have increased anthropogenic activities, contained ten-times less than values found in Ortigueira Ria. This is also true for observations as in other estuaries with anthropogenic contamination, 
such as the Canon in Taiwan (Cr: $192 \mathrm{mg} \cdot \mathrm{kg}^{-1}$, Chen et al., 2012), and Elbe in Germany (Cr: 108 $\mathrm{mg} \cdot \mathrm{kg}^{-1}$, Wetzel et al., 2013). In the Galician coast, extremely higher $\mathrm{Cr}$ and Ni concentrations ( $\mathrm{Cr}: 627 \mathrm{mg} \cdot \mathrm{kg}^{-1}$; Ni: $357 \mathrm{mg} \cdot \mathrm{kg}^{-1}$ ) were only found in sediments of Arosa Ria due to severe contamination from old tanneries effluents (Prego et al., 2008) unlike the increased levels in Ortigueira Ria that have a natural source (Ortegal Cape).

Results also indicate that atmospheric transport is a pathway introducing $\mathrm{Cr}$, Ni mainly, and Co also to the adjacent coastal environments (Fig.4 and 5). Due to the absence of anthropogenic activities in the area, the weathering of Ortegal Complex rocks is the presumably the process that mobilizes these elements in rain Concentrations increased in precipitation collected at the meteorological station of Cape Estaca-de-Bares when the wind was blowing from Cape Ortegal direction. Wind promotes soil resuspension transporting particles enriched with metals to the aquatic environment.

Thus, the input of $\mathrm{Cr}, \mathrm{Ni}$ and $\mathrm{Co}$ to Ortigueira and Barqueiro Rias is from natural origin unlike most of published works that showed increases of metals associated with industrial or urban emissions (e.g. Adejumo et al., 1994; Hu et al., 2003; Song and Gao, 2009; Sakata and Akasura, 2009; González-Miqueo et al., 2010; Bermudez et al., 2010; Pal et al., 2011). In fact, Fernandez and Carballeira (2000) have attributed the increased concentrations of $\mathrm{Cr}$ in mosses from the Northern Galician area to the soil lithology. According to European and Canadian Soil Guide line Values (CCME, 2007; Pal et al., 2011) the maximum concentrations of $\mathrm{Co}, \mathrm{Cr}$ and $\mathrm{Ni}$ in air particles were within the limits for agricultural, residential and industrial land use.

Weathering of the river basins is another pathway that introduces $\mathrm{Cr}$ and $\mathrm{Ni}$ into the Ortigueira Ria since higher concentrations of these metals were found in the dissolved fraction and suspended particulate matter of Lourido and Landoi Rivers (Table 3 and Fig. 6). This input may be related to the geology of these basins that includes the Ortegal Complex. The reason for the higher concentration of $\mathrm{Ni}$ may be due to the solubility of the minerals containing this element. Nickle sulfides are more soluble in rain water $(\mathrm{pH} 5.8 \pm 1.1$ in Estaca-de-Bares station during 2008) than $\mathrm{Cr}$ oxides from their minerals, suggesting why $\mathrm{Ni}$ was more abundant in the dissolved phase while $\mathrm{Cr}$ did in the particulate (Table 3).

The strong correlations between Lourido River discharges and metals concentrations could be related to an increase concentration of particulate matter due to sediment resuspension associated with river flow and enhanced transfer of metals from soils. In order to evaluate changes in the partitioning of $\mathrm{Cr}, \mathrm{Ni}$ and $\mathrm{Co}$ between the dissolved and the particulate fractions, distribution coefficients for each element (Kd=[Me $]_{\text {SPM }} /[\mathrm{Me}]_{\text {diss; }}$ Millward and Turner, 1995) were calculated. Interestingly, minor variability during the surveyed period with low coefficient variation of the mean for each element was found. Calculated mean values and standard 
deviation of $\log \mathrm{Kd}(\mathrm{Co})$ were similar between the three rivers that flow Ortigueira $(3.1 \pm 0.4$ for Lourido; $3.2 \pm 0.4$ for Landoi and $2.7 \pm 0.4$ for Mera) and with the Sor River that runs into the

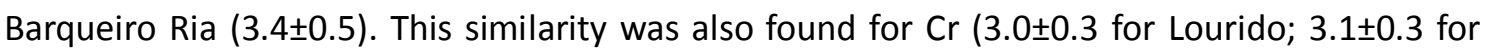
Landoi, $3.8 \pm 0.3$ for Mera and 3.7 \pm 0.4 for Sor), and Ni (1.8 \pm 0.2 for Lourido; $2.3 \pm 0.2$ for Landoi, 2.1 \pm 0.3 for Mera and 1.6 \pm 0.4 for Sor) suggesting an equilibrium between the dissolved and the particulate fraction for the studied metals. Furthermore increases of river flow and consequently of suspended particulate material does not influence the water-particle partitioning. Thus, it is hypothesized that the increased river flow promotes weathering and consequent transfer of $\mathrm{Cr}, \mathrm{Ni}$ and $\mathrm{Co}$ from the basin rocks to the water column. Enhanced $\mathrm{Cr}$ concentrations related to weathering of mafic rocks and Precambrian Shield derived glacial deposits have been found in river and stream waters that discharge in the Baltic Sea (De Vos and Tarvainen, 2006). These authors also report high $\mathrm{Ni}$ concentrations in stream water on entirely barren soil and sediments in north-eastern Europe. The other two rivers, Mera (Ortigueira Ria) and Sor (Barqueiro Ria) cross a different geological domain (Ollo de Sapo) characterized by metamorphic (mainly gneisses) and granite-type rocks poorer in $\mathrm{Cr}$ and $\mathrm{Ni}$ (Aparicio et al, 1987; Marcos, 2004). Therefore, concentrations of $\mathrm{Co}, \mathrm{Cr}$ and $\mathrm{Ni}$ found in these fluvial end-members are closer to background values described by De Vos and Tarvainen (2006).

To better understand the relevance of the different inputs of $\mathrm{Cr}, \mathrm{Ni}$, and $\mathrm{Co}$ to Ortigueira and Barqueiro Rias annual fluxes were calculated for each river and for rainfall (Table 3). Although elevated concentrations of $\mathrm{Cr}$ and $\mathrm{Ni}$ have been found in Lourido and Landoi Rivers the calculated annual fluxes were lower than the contribution of Sor River in Barqueiro Ria, which have higher discharge rates and larger watershed. In spite of that, the rivers that flow to Ortigueira Ria introduce more $\mathrm{Cr}, \mathrm{Ni}$ and $\mathrm{Co}$ than the Sor discharges into the Braqueiro Ria. Airborne fluxes have a minor contribution of $\mathrm{Ni}$ and Co to both rias corresponding to 10 to $20 \%$ of the total annual flux derived from rivers. Otherwise, the atmospheric input of $\mathrm{Cr}$ represents $25 \%$ of the annual river flux to Ortigueira Ria, and $35 \%$ to the Barqueiro Ria, indicating that rain (dissolved + particulate) is an important vector introducing this element into the aquatic environment.

The higher accumulation of $\mathrm{Cr}$ and $\mathrm{Ni}$ in aquatic organisms from Ortigueira Ria demonstrates the influence of the Ortegal Complex on the bio-availability of those metals (Table 2). Although mussels are subjected to higher dissolved and particulate concentrations of $\mathrm{Cr}$ and $\mathrm{Ni}$ via the Lourido River concentrations were lower than those reported by Puente et al. (1996) and Carballeira et al. (2000) in the NW Spain. Otherwise, levels of Ni were higher compared to M. edulis from the French Cantabric coast (Roux et al., 2001). Several works point 
that the major pathway of accumulation in mussels derives from both water and filtered suspended sediments (Wang and Fisher, 1999). However, the low labile fraction of both $\mathrm{Cr}$ and $\mathrm{Ni}$ in sediments found in both rias points that bioaccumulation of both elements occurred through the dissolved fraction. The higher concentrationss of $\mathrm{Cr}$ and $\mathrm{Ni}$ in mussel soft tissues in comparison to the shells suggest low metal transfer during shell secretion from mantle epithelium. The mismatch between accumulation in shells and soft tissues may be related to local environmental conditions like changes of ionic strength, $\mathrm{pH}$ and temperature between seasons that not favor trace element retention during biomineralization (Putten et al., 2000). Strong correlations were found between $\mathrm{Cr}$ and $\mathrm{Ni}$ concentrations in whole soft tissues $(r=0.90$; $p<0.05)$ and in shells $(r=0.89 ; p<0.05)$ suggesting a by-synergic interaction among them. However, the relationship slopes points to the efficient accumulation of $\mathrm{Cr}$ and/or increased elimination of $\mathrm{Ni}$. The higher uptake of $\mathrm{Cr}$ may be related with its speciation in seawater $\left(\mathrm{CrO}_{4}{ }^{2-}\right.$ ) favoring the transport through anionic membrane channels as phosphate or sulfate analogues (Putten et al., 2000). Since $\mathrm{Ni}$ is considered an essential element, regulation mechanisms may also be implied. Similarly spatial trend was found the brown algae $F$. vesiculosus collected at Barqueiro Ria with higher $\mathrm{Cr}$ and $\mathrm{Ni}$ accumulation in their tissues induced by the flow of Lourido River water enriched in those metals. The observed concentrations were lower than those reported by Villares et al. (2007). Nevertheless, a clear difference was found between the two studied species since no correlation was found between levels of $\mathrm{Cr}$ and $\mathrm{Ni}$ in algae tissues. The presented results do not allow evaluating the reason of a non-synergetic accumulation but low sorption of $\mathrm{Ni}$ was attributed to the lower selectivity coefficient for alginates (Holan and Volesky, 1994).

\section{CONCLUSION}

The results obtained in this study point to the influence of the Ortegal Complex on the distribution of $\mathrm{Cr}, \mathrm{Ni}$ and $\mathrm{Co}$ in surface sediments of the coastal region and concentrations in river waters crossing this geological feature. Mechanisms of input include soil erosionand air transport. Inputs increase thebioavailability of these elements in the Ortigueira Ria to Mytilus galloprovincialis and in Fucus vesiculosus.

The coastal zone is a boundary environment where land, sea, atmosphere, and human activities are joined. The geologic setting as demonstrated by the, data collected at Cape Ortegal, that is underlain by an ultramafic complex and in an areas of low anthropogenic contamination, is important for influencing land-sea exchange of trace metals. Metal enrichment in water, sediments, and biota due to natural conditions should be carefully when developing environmental management strategies. 
Aknowledgements: The manuscript has benefited greatly from the reviews of the anonymous referees and the editing and comments of the Assistant Editor - Dr. Mae Gustin. Authors thank the crew and staff of INTERESANTE project cruises on board the IEO R.V. Lura and CSIC R.V. Mytilus for their kind assistance during the field sampling and laboratory analysis. We also acknowledge to the 'Delegación Territorial de Lugo de la Consellerí́a do Mar (Xunta de Galicia)' for laboratory facilities in Celeiro Harbour; 'Augas de Galicia' for the river flows of gauging stations; the 'AEMET (Gobierno de España)' for meteorological data of the Estaca-de-Bares station. This article is a contribution to the Spanish LOICZ program and was supported by the research projects INTERESANTE (ref. CTM2007-62546-C03/MAR) and MITOFE (ref. CTM201128792-C02) financed by CICYT and MINECO, respectively, in cooperation with the SpanishPortuguese Action references 2007PT0021 and 9/CSIC/2008. M.Sc. N. Ospina-Alvarez expresses gratitude to CSIC support by means of a JAE-preDoc contract.

\section{REFERENCES}

Adejumo, J., Obioh, I., Ogunsola, O., Akeredolu, F., Olaniyi, H., Asubiojo, O., Oluwole, A., Akanle, O., Spyrou, N., 1994. The atmospheric deposition of major, minor and trace elements within and around three cement factories. J. Radioanal. Nucl. Chem. 179, 195-204.

Alexander, E., Adamson, C., Zinke, P., Graham, R., 1989. Soils and conifer forest productivity on serpentinized peridotite of the Trinity Ophiolite California. Soil Science, 146, 412-423

Aparicio, A., Sánchez Cela, V., Cacho, L.E., 1987. Petrological and geochemical considerations of the Cabo Ortegal Complex (NW Spain). Rev. Real Acad. Cienc. Zaragoza 42, 131-162.

Bermudez, G., Moreno, M., Invernizzi, R., Plá R., Pignata, M., 2010. Heavy metal pollution in topsoils near a cement plant: The role of organic matter and distance to the source to predict total and $\mathrm{HCl}$-extracted heavy metal concentrations. Chemosphere 78, 375-381

Bernárdez, P., Prego, R., Giralt, S., Esteve, J., Caetano, M., Parra, S., Francés, G., 2012. Geochemical and mineralogical characterization of surficial sediments from the Northern Rias: implications for sediment provenance and impact of the source rocks. Marine Geology 291-294, 63-72.

Bowen, H.J.M., 1966. Trace elements in biochemistry. Academic Press, London.

Caetano, M., Vale, C., Cesário, R., Fonseca, N., 2008. Evidence for preferential depths of metal retention in roots of salt marsh plants. Science Total Environment 390, 466-474.

Carballeira, A., Carral, E., Puente, X., Villares, R., 2000. Regional scale monitoring of coastal contamination. Nutrients and heavy metals in estuarine sediments and organisms on the 
coast of Galicia (northwest Spain). International Journal of Environment and Pollution 13, 534-572.

CCME (Canadian Council of Ministers of the Environment), 2007. Canadian Soil Quality Guidelines for the Protection of Environmental and Human Health, Winnipeg.

Chen, C.-W., Chen, C.-F., Dong, C.-D., 2012. Evaluation of Chromium contamination in the surface sediments of Canon River estuary, Taiwan. Advanced Materials Research 550-553, 2117-2120.

Cho, Y.-G., Lee, C.-B., Choi, M.-S., 1999. Geochemistry of surface sediments off the southern and western coasts of Korea. Marine Geology 159, 111-129.

Dallmeyer, R., Martínez-Catalán, J., Arenas, R., Gil-Ibarguchi, J., Gutiérrez-Alonso, G. Farias, P., Bastida, F., Aller, J., 1997. Diachronous Variscan tectonothermal activity in the NW Iberian Massif: Evidence from 40Ar/39Ar dating of regional fabrics. Tectonophysics 227, 307-337.

De Vos, W., Tarvainen, T., 2006 Geochemical Atlas of Europe. Part 2: Interpretation of geochemical maps, additional tables, figures, maps and related publications. (Espoo, Geological Survey of Finland. http://www.gtk.fi/publ/foregsatlas/part2.php)

Fendorf, S., Wielinga, B., Hanse, C., 2000. Chromium transformations in natural environments: The role of biological and abiological processes in chromium (VI) reduction. Int. Geol. Rev. $42,691-701$.

Fernandez, J., Carballeira, A., 2000. An extended study of heavy metal deposition in Galicia NW Spain/ based on moss analysis. Sci.Total Environ. 254, 31-44.

Ferreira, A.M., Cortesão, C., Castro, O., Vale, C., 1990. Accumulation of metals and organochlorines in tissues of the oyster Crassostrea angulata from the Sado estuary. Sci. Total Environ. 97/98, 239-627.

Firek, F., Shideler, G., Fleischer, P., 1977. Heavy-mineral variability in bottom sediments of the lower Chesapeake Bay, Virginia. Mar. Geol. 23, 217-235.

Förstner, U., 1987. Sediment-associated contaminants. An overview of basis for developing remedial options. Hydrologia 149, 221-246.

Gasser, U., Dhlgreen, R., 1994. Solid phase speciation and surface association of metals in serpentinic soils. Soil Science, 158, 409-420

Gent, R., Menéndez-Álvarez, M., García-Iglesias, J., Taraño-Álvarez, J., 2005. Offshore occurrences of heavy mineral placers, Northwest Galicia, Spain. Mar. Georesources Geotechnol. 23, 39-59.

Gil-Ibarguchi, J.I., Mendia, M., Girardeau, J., Peucat, J.J., 1990. Petrology of eclogites and clinopyroxenegarnet metabasites from the Cabo Ortegal Complex (northwestern Spain). Lithos 25, 133-162. 
González-Miqueo, L., Elustondo, D., Lasheras, E., Santamaría, J., 2010. Use of native mosses as biomonitors of heavy metals and nitrogen deposition in the surroundings of two steel works. Chemosphere 78, 965-971.

Goyer, R.A., 1991. Toxic effects of metals, In: Amer M., Doul J, Klaassen C. (ed) Casarett and Doull's Toxicology; Basic Science of Poisons. Pergamon Press, Oxford.

Holan, Z.R., Volesky, B. 1994. Biosorption of Lead and Nickel by biomass of marine algae. Biotechn. Bioeng. 43, 1001-1009.

Hornberger, M.I., Luoma, S.N., Van Geen, A., Fuller, C., Anima, R., 1999. Historical trends of metals in the sediments of San Francisco Bay, California. Mar. Chem. 64, 39-55.

Hu, C., Chao, M., Wu, K., Chang-Chien, G., Lee, W., Chang, L., Lee, W., 2003. Characterization of multiple airborne particulate metals in the surroundings of a municipal waste incinerator in Taiwan. Atmos. Environ. 37, 2845-2852.

IGME, 1977. Mapa geológico de España. Hoja de Cariño (1:50.000), Instituto Geológico Minero de España, Madrid.

Kiratli, N., Erguin, M., 1996. Partitioning of heavy metals in surfaceBlack Sea sediments. Appl. Geochem. 11, 775-788.

Lorenzo, F., Alonso A., Pellicer M.J., Pagés J.L., Pérez-Arlucea M., 2007. Historical analysis of heavy metal pollution in three estuaries on the north coast of Galicia (NW Spain). Environ. Geol. 52, 789-802.

Marcos A., 2004. Zona Asturooccidental-Leonesa, in: Vera, J.A. (Ed.), Geología de España, SGEIGME, Madrid, 49-68.

Martínez-Catalán, J., Arenas, R., Díaz-García, F., Rubio-Pascual, F., Abati, J., Marquínez, J., 1996. Variscan exhumation of a subducted Paleozoic continental margin: The basal units of the Ordenes Complex, Galicia, NW Spain. Tectonics 15, 106-121.

Merian, E., 1991. Metals and their compounds in the environment. WCH, Weinhein.

Millward G, Turner, A., 1995. Trace metals in estuaries. In: Salbu B, Steiness E, editors. Trace elements in Natural Waters. CRC Press, Boca Raton, FL; 223-245.

Mirre, J.C., 1990. Guia dos minerais de Galicia. Editorial Galaxia, Vigo, Spain, 194 pp.

Moreno, T., Gibbons, W., Prichard, H., Lunar, R., 2001. Platiniferous chromitite and the tectonic setting of ultramafic rocks in Cabo Ortegal, NW Spain. Journal of the Geological Society $158,601-614$

Otero, X.L., Huerta-Diaz, M.A., Macias, F. 2000. Heavy metal geochemistry of saltmarsh soils from the Ria of Ortigueira (mafic and ultramafic areas, NW Iberian Peninsula). Environ Pollut 110, 285-296 
Otte, R., 1991. Heavy metals and arsenic in vegetation of salt marshes and flood plains. Ph.D. thesis, Free University, Amsterdam.

Pal, S., Wallis, S., Arthur, S., 2011. Assessment of heavy metals emission from traffic on road surface. Cent. Eur. J. Chem. 9, 314-319.

Peucat, J.J., Bernard-Griffiths, J., Dallmeyer, R.D., Menot, P., Cornichet, J., Iglesias Ponce de Leon, M., Gil-Ibarguchi, J.I., 1990. Geochemical and geochronological cross-section of the deep Hercynian crust: the Cabo Ortegal high-pressure nappes (NW Spain). Tectonophysics $177,263-292$.

Prego, R., Cobelo-Garcia, A., 2003. Twentieth century overview of heavy metals in the Galician Rias (NW Iberian Peninsula). Environ. Pollut. 121, 425-452.

Prego R., Belzunce M.J., Cobelo-García A., Helios-Rybicka E., 2008. Particulate metal in the Ulla River estuary: State and sources of contamination (Arosa Ria, NW Iberian Peninsula). Ciencias Marinas 34, 381-388.

Prego, R., Caetano, M., Vale, C., Marmolejo-Rodríguez, J., 2009. Rare earth elements in sediments of the Vigo Ria, NW Iberian Peninsula. Cont. Shelf Res. 29, 896-902.

Puente, X., Villares, R., Carral, E., Carballeira, A., 1996. Nacreous shell of Mytilus galloprovincialis as a biomonitor of heavy metal pollution in Galiza (NW Spain). Sci. Total Environ. 183, 205-211.

Putten, E., Dehairs, F., Keppens, E., Baeyens, W., 2000. High resolution distribution of trace elements in the calcite shell layer of modern Mytilus edulis: Environmental and biological controls. Geochimica et Cosmochimica Acta 64, 997-1011.

Quevauviller, P.H., Rauret, G., Lopez-Sanchez, J.F., Rubio, R., Ure, A.M., Muntau, H., 1997. The certification of the EDTA-extractable contents (mass fractions) of $\mathrm{Cd}, \mathrm{Cr}, \mathrm{Ni}, \mathrm{Pb}$ and $\mathrm{Zn}$ in sediment following a three-step sequential extraction procedure, Report EUR 17554 EN, Brussels, European Commission.

Rantala R., Loring, D., 1975. Multi-element analysis of silicate rocks and marine sediments by atomic absorption spectrophotometry. Atomic Absorption Newsletter 14, 117-120.

Roux, N., Chiffoleau, J., Claisse, D., 2001. L'argent, le cobalt, le nickel et le vanadium dans les mollusques du littoral français Surveillance du milieu marin. Travaux du Réseau National d'Observation de la qualité du milieu marin. 11-20.

Rubio, B., Pye, K., Rae, J., Rey, D., 2001. Sedimentological characteristics, heavy metal distribution and magnetic properties in subtidal sediments, Ria de Pontevedra, NW Spain. Sedimentology 48, 1277-1296. 
Sakata, M., Asakura, K., 2009. Factors contributing to seasonal variations in wet deposition fluxes of trace elements at sites along Japan Sea coast. Atmospheric Environment 43, 3867-3875.

Schreier, H., Omueti, J., Lavkulich, L., 1987. Weathering proceses of asbestos-rich serpentinic sediments. Soil Science Society of American Journal 72, 770-774

Song, F., Gao, Y., 2009. Chemical characteristics of precipitation at metropolitan Newark in the US East Coast. Atmospheric Environment 43, 4903-4913

Turner, A., 2000. Trace metal contamination in sediments from UK estuaries: an empirical evaluation of the role of hydrous iron manganese oxides. Estuarine Costal Shelf Science 50: $355-371$

Vilas, F., Bernabeu, A., Méndez, G., 2005. Sediment distribution pattern in the Rias Baixas (NW Spain): main facies and hydrodynamic dependence. Journal of Marine Systems 54, 261276.

Villares, R., Real, C., Fernandez, J.A., Aboal, J., Carballeira, A., 2007. Use of an environmental specimen bank for evaluating the impacts of the Prestige oil spill on the levels of trace elements in two species of Fucus on the coast of Galicia (NW Spain). Sci. Total Environ. 374, 379-387.

Wang, X., Fisher, N., 1999. Delineating metal accumulation pathways for marine invertebrates. Science of the Total Environment 237/238, 459-472

Wetzel, M.A., Wahrendorf, D.-S., von der Ohe, P.C., 2013. Sediment pollution in the Elbe estuary and its potential toxicity at different trophic levels. Science of the Total Environment 449, 199-207.

Windom, H.L., Schropp, S.J., Calder, F.D., Ryan, J.D., Smith, R.G., Burney, L.C., Lewis, F.G., Rawlinson, C.H., 1989. Natural trace metal concentrations in estuarine and coastal marine sediments of the southeastern United States. Environ. Sci. Technol. 23, 314-320. 


\section{FIGURES CAPTIONS}

Figure 1. Map of the main coastal geological units, which affect the river-ria-shelf system of the two westernmost Northern Galician Rias, and the sediment, rainfall, river and biological sampling stations.

Figure 2. Distribution of grain size, $\mathrm{Al}, \mathrm{Mg}, \mathrm{Cr}, \mathrm{Ni}$ and $\mathrm{Co}$ in surface sediments of Ortigueira and Barqueiro Rias and the coastal area around the Capes Ortegal and Estaca-de-Bares.

Figure 3. Linear regression of $\mathrm{Cr}$ vs. $\mathrm{Mg}, \mathrm{Ni}$ vs. $\mathrm{Cr}$, and $\mathrm{Co}$ vs. $\mathrm{Ni}$ contents in the surface sediments of Ortigueira and Barqueiro Rias and the coastal area around the Capes Ortegal and Estaca-de-Bares. Outliers $(x)$ were identified by a Grubbs' test $(p<0.05)$ and removed from the original data set.

Figure 4. Rainfall and the fluxes of total $\mathrm{Cr}$, $\mathrm{Ni}$ and $\mathrm{Co}$ collected in the meteorological station of Estaca-de-Bares during 2008.

Figure 5. Compass rose in the meteorological station of Estaca-de-Bares from the daily data recorded during 2008. Rose shows as the westerly winds were the more strong and prevalent. Linear regression of total $\mathrm{Cr}$ concentration in the rainfall samples collected in that meteorological station during 2008 vs. the speed of westerly winds averaged to each sample period.

Figure 6. Box and whisker plots of $\mathrm{Cr}, \mathrm{Ni}$ and $\mathrm{Co}$ concentrations in water $\left(\mu \mathrm{g} \cdot \mathrm{L}^{-1}\right)$ and suspended particulate matter $\left(\mathrm{mg} \mathrm{kg}^{-1}\right)$ of the main fluvial contributions to Ortigueira (Lourido, Landoi and Mera rivers) and Barqueiro (Sor river) Rias. Horizontal lines correspond to the median and the edges of the box the $25^{\text {th }}$ and $75^{\text {th }}$ percentiles, respectively. Mean values are shown as a cross symbol (+). 


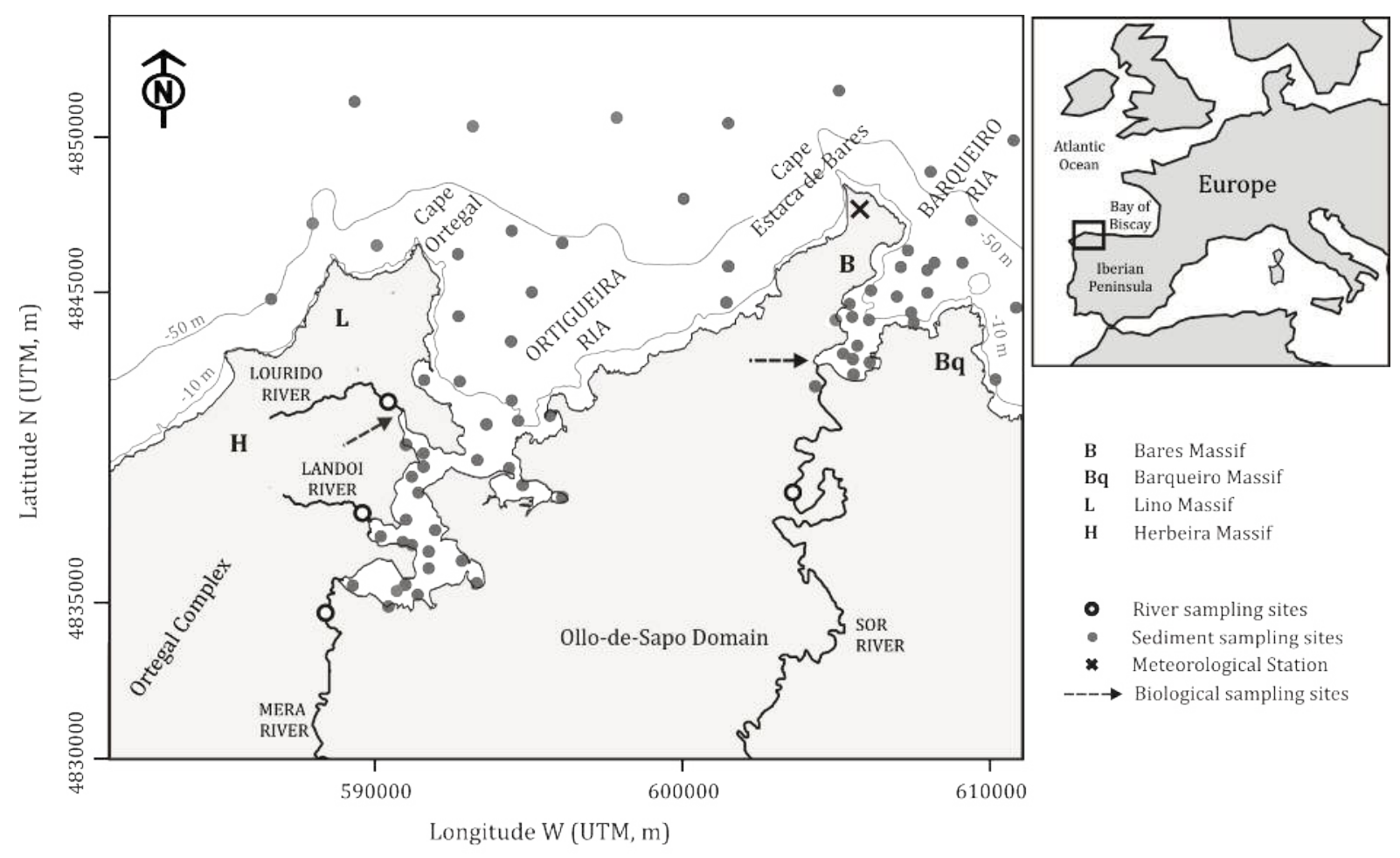

Figure 1 

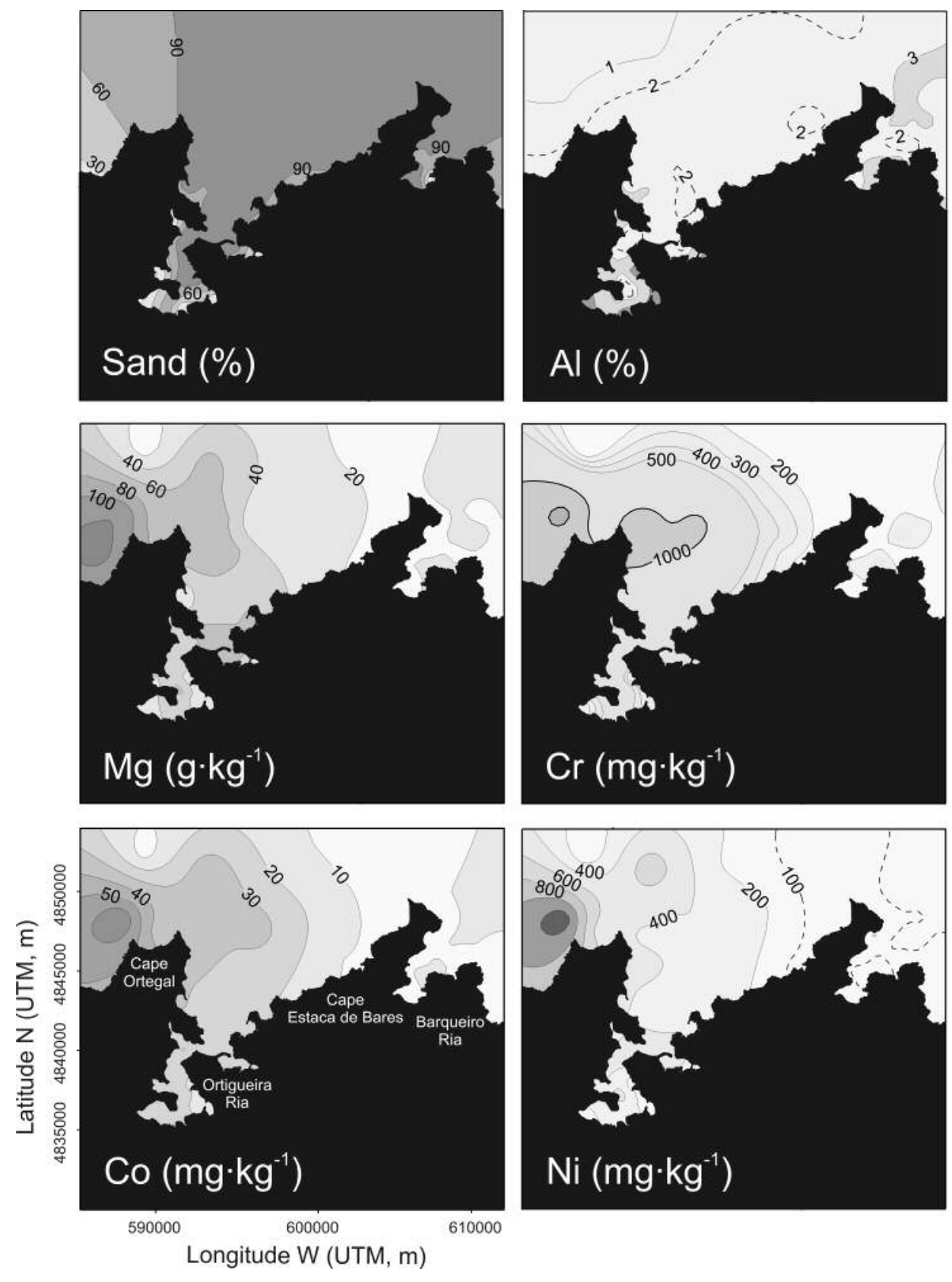

\section{$\mathrm{Ni}\left(\mathrm{mg} \cdot \mathrm{kg}^{-1}\right)$}

Figure 2 

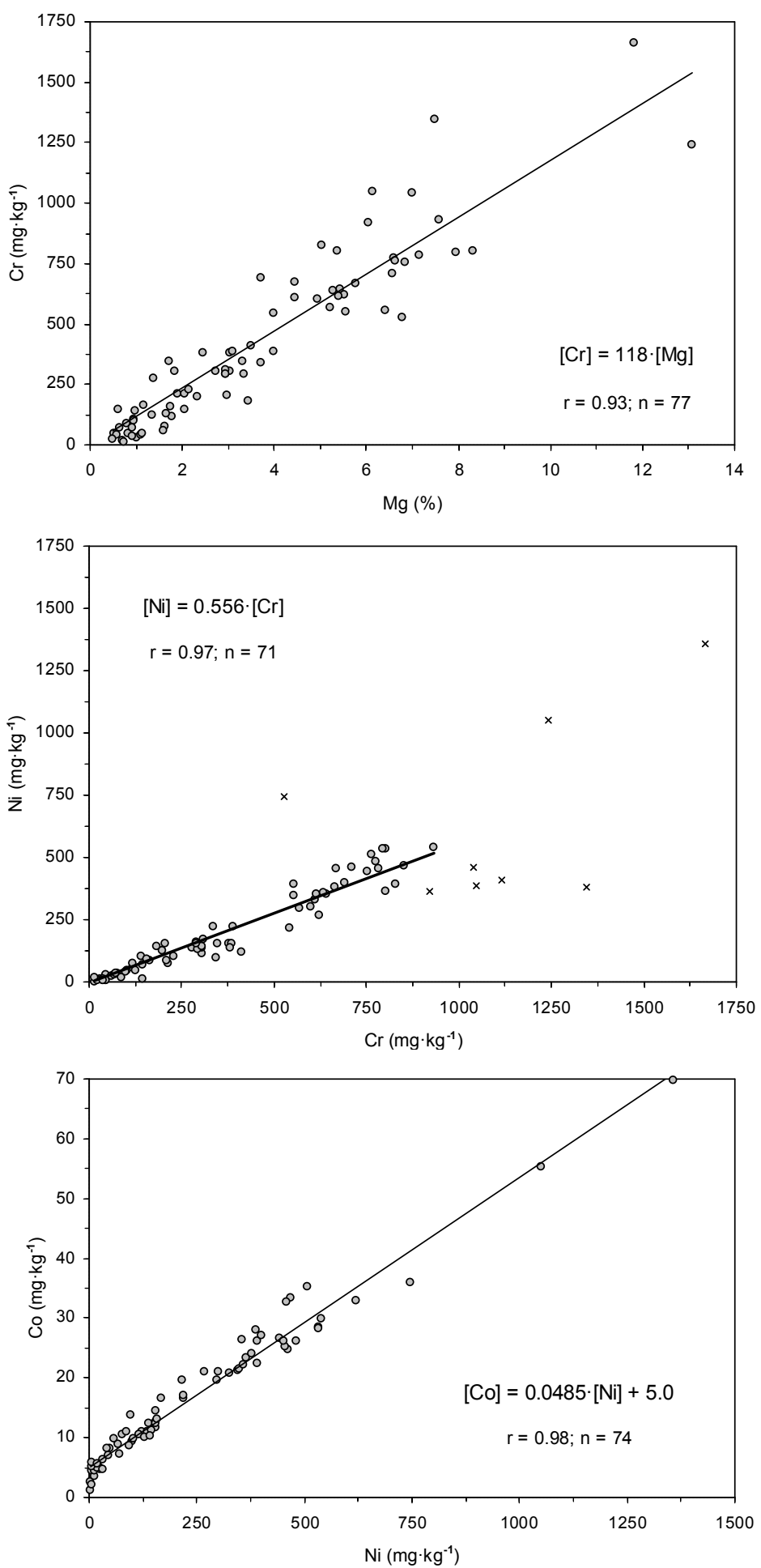

Figure 3 


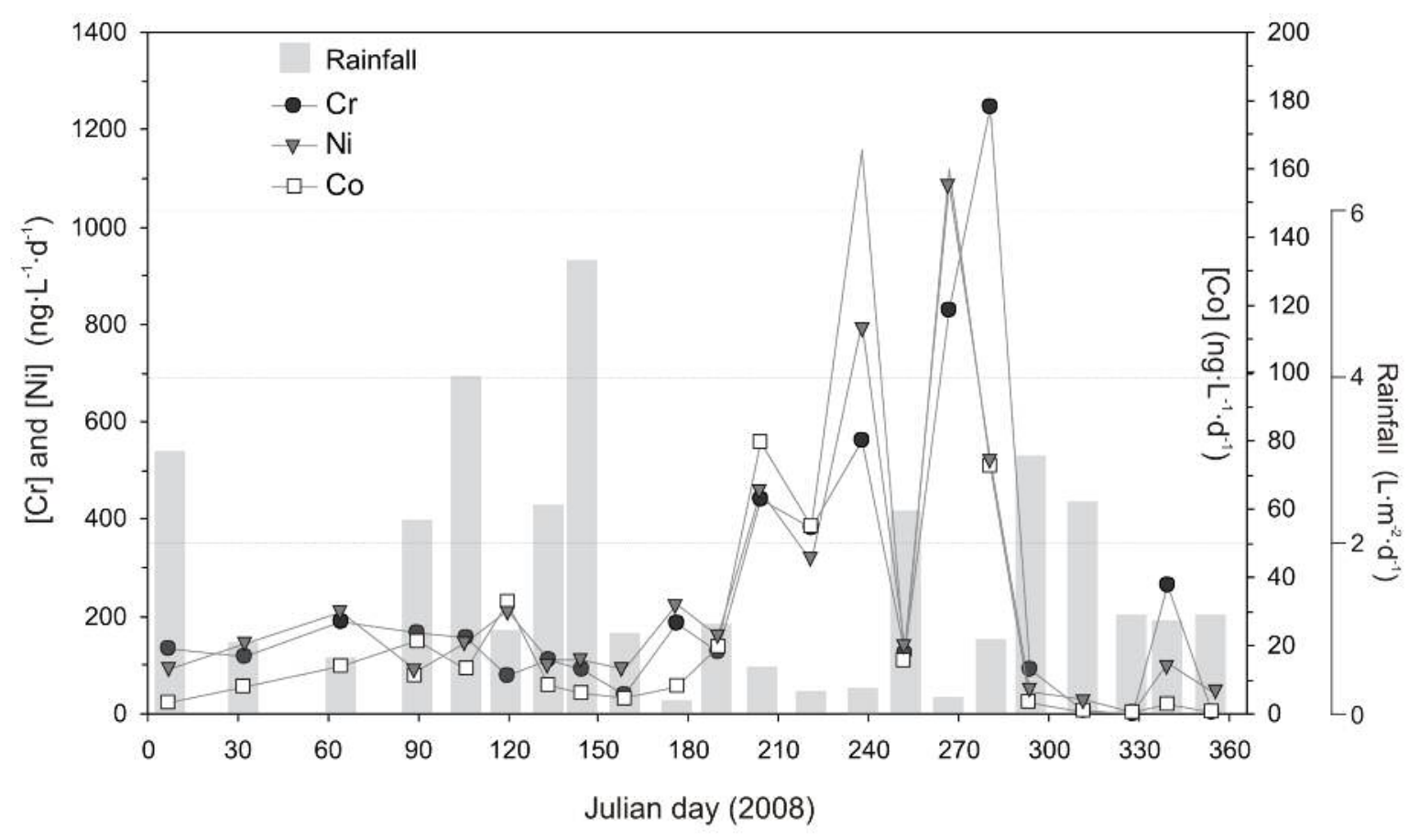

Figure 4 


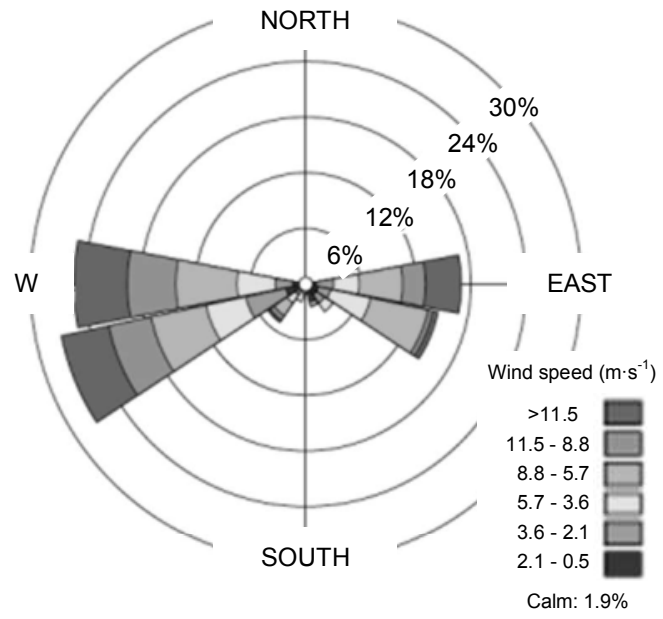

Wind Rose

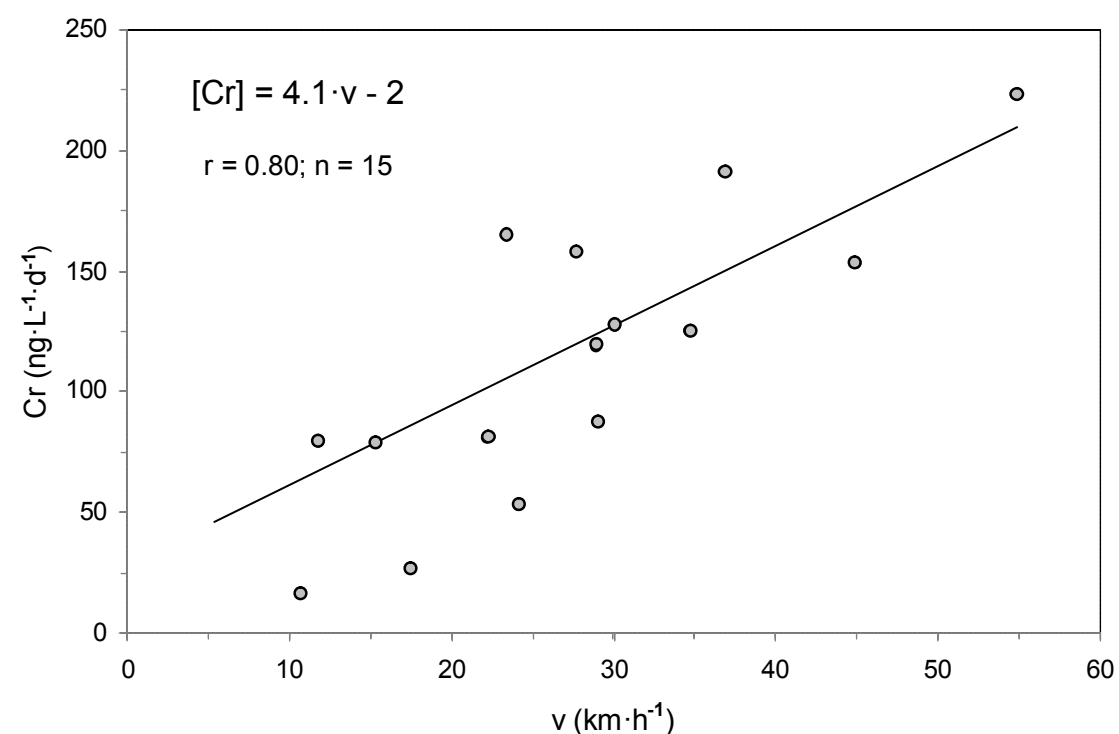

Figure 5 

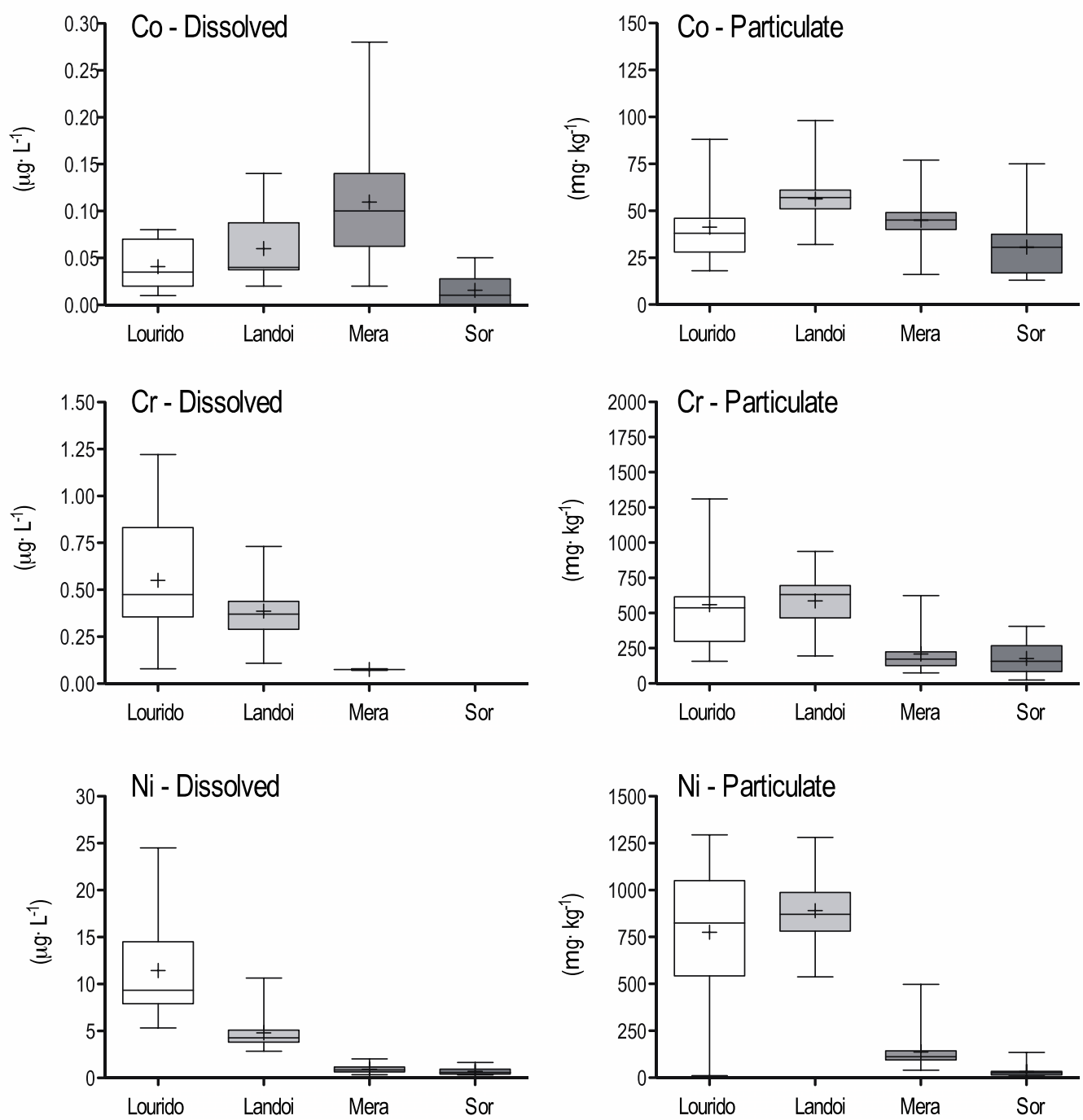

Figure 6 
Table 1 - Certified and measured average concentrations and standard deviations $(n=5)$ in the certificate reference materials: PACS-2 (marine sediment); BCR CRM 701 (lake sediment) used to check the first step of SM\&T metal extraction; NBS 1566a for biological material; and SLRS-4 (river water reference material).

\begin{tabular}{|c|c|c|c|c|c|}
\hline $\begin{array}{c}\text { Al } \\
\left(\mathrm{g} \cdot \mathrm{kg}^{-1}\right)\end{array}$ & $\begin{array}{c}\mathrm{Mg} \\
\left(\mathrm{g} \cdot \mathrm{kg}^{-1}\right)\end{array}$ & $\begin{array}{c}\text { Co } \\
\left(\mathrm{mg} \cdot \mathrm{kg}^{-1}\right)\end{array}$ & $\begin{array}{c}\mathrm{Cr} \\
\left(\mathrm{mg} \cdot \mathrm{kg}^{-1}\right)\end{array}$ & $\begin{array}{c}\mathrm{Ni} \\
\left(\mathrm{mg} \cdot \mathrm{kg}^{-1}\right)\end{array}$ & \\
\hline $66.1 \pm 5.3$ & $1.47 \pm 0.13$ & $11.5 \pm 0.3$ & $90.7 \pm 4.6$ & $39.5 \pm 2.3$ & Certified in PACS-2 \\
\hline $62.7 \pm 4.4$ & $1.36 \pm 0.13$ & $11.2 \pm 0.3$ & $86.1 \pm 3.4$ & $40.5 \pm 2.6$ & Obtained \\
\hline-- & -- & -- & $2.26 \pm 0.16$ & $15.4 \pm 0.9$ & Certified in BCR CRM 701 \\
\hline-- & -- & -- & $2.47 \pm 0.09$ & $15.3 \pm 0.1$ & Obtained \\
\hline-- & -- & -- & $1.43 \pm 0.46$ & $2.25 \pm 0.44$ & Certified in NBS 1566a \\
\hline \multirow[t]{2}{*}{--} & -- & -- & $1.21 \pm 0.01$ & $1.91 \pm 0.01$ & Obtained \\
\hline & & $(\mathrm{nM})$ & $(\mathrm{nM})$ & $(\mathrm{nM})$ & \\
\hline-- & -- & $0.56 \pm 0.10$ & $6.3 \pm 0.4$ & $11.4 \pm 1.4$ & Certified in SLRS-4 \\
\hline-- & -- & $0.47 \pm 0.04$ & $5.5 \pm 0.3$ & $10.7 \pm 0.4$ & Obtained \\
\hline
\end{tabular}


Table 2 - Median and range concentrations of metals in the shell and whole soft tissue of mussel (Mytilus galloprovincialis) and fucus (Fucus versiculosus) collected in 2008 at Lourido (Ortigueira Ria) and Sor (Barqueiro Ria) rivers.

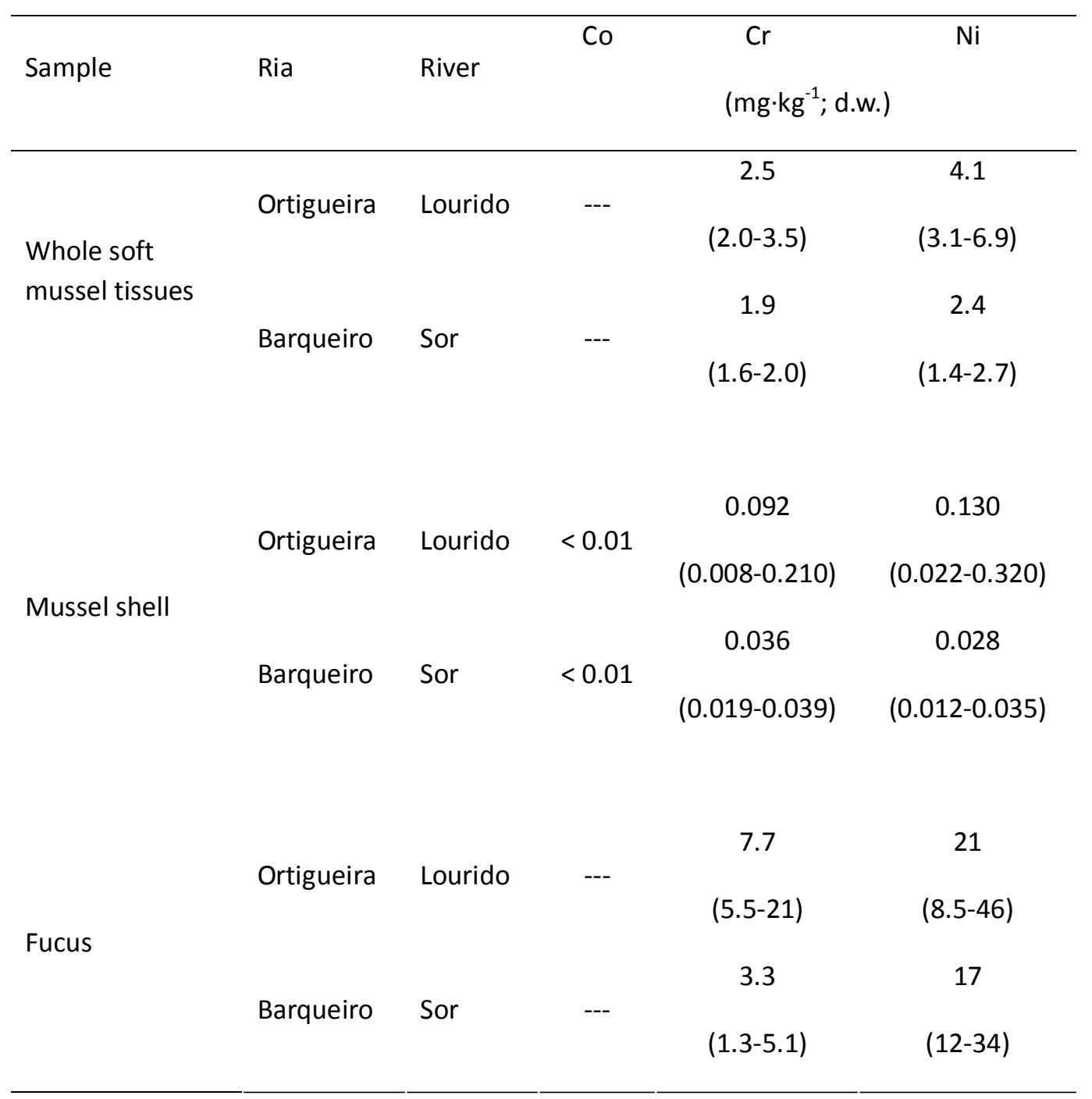


Table 3 - Annual average of flows and concentrations of total trace metals and its dissolved fraction percentage in the fluvial and rain waters running into Ortigueira and Barqueiro Rias. Annual contributions of metals are also shown. Fluxes of metals in the precipitation were calculated from data in the meteorological station of Estaca-de-Bares and the surface area of both rias $\left(48 \mathrm{~km}^{2}\right)$.

\begin{tabular}{|c|c|c|c|c|c|c|c|c|c|c|}
\hline \multirow[t]{4}{*}{ Source } & \multirow{4}{*}{$\begin{array}{l}\text { Water } \\
\text { flow } \\
\left(\mathrm{m}^{3} \cdot \mathrm{s}^{-1}\right)\end{array}$} & \multicolumn{6}{|c|}{ Concentration } & \multicolumn{3}{|c|}{ Annual Flux } \\
\hline & & \multicolumn{2}{|c|}{ Co } & \multicolumn{2}{|c|}{$\mathrm{Cr}$} & \multicolumn{2}{|c|}{$\mathrm{Ni}$} & \multirow[t]{3}{*}{ Co } & \multirow{3}{*}{$\begin{array}{c}\mathrm{Cr} \\
\text { Total } \\
\left(\mathrm{kg} \cdot \mathrm{y}^{-1}\right)\end{array}$} & \multirow[t]{3}{*}{$\mathrm{Ni}$} \\
\hline & & Total & Diss. & Total & Diss. & Total & Diss. & & & \\
\hline & & $\left(\mu \mathrm{g} \cdot \mathrm{L}^{-1}\right)$ & $(\%)$ & $\left(\mu \mathrm{g} \cdot \mathrm{L}^{-1}\right)$ & (\%) & $\left(\mu \mathrm{g} \cdot \mathrm{L}^{-1}\right)$ & $(\%)$ & & & \\
\hline Lourido Stream & 0.48 & 0.16 & 24 & 2.26 & 27 & 12.96 & 87 & 3.3 & 44 & 198 \\
\hline Landoi Stream & 1.03 & 0.61 & 9 & 4.90 & 9 & 11.81 & 41 & 10 & 97 & 213 \\
\hline Mera River & 5.97 & 0.20 & 53 & 0.41 & $<5$ & 1.20 & 81 & 37 & 80 & 212 \\
\hline Sor River & 19.30 & 0.04 & 40 & 0.23 & $<5$ & 0.73 & 96 & 27 & 162 & 547 \\
\hline Rainfall & -- & 0.22 & -- & 2.21 & -- & 2.08 & -- & 5.5 & 56 & 53 \\
\hline
\end{tabular}

